\title{
The Role of Cytochromes and Blue Copper Proteins in Growth of an Obligate Methylotroph on Methanol and Methylamine
}

\author{
By KEVIN A. AUTON AND CHRISTOPHER ANTHONY* \\ Biochemistry Department, University of Southampton, Southampton SO9 3TU, UK
}

(Received 13 October 1988; revised 6 March 1989; accepted 17 March 1989)

\begin{abstract}
The aim of this work was to determine the extent to which the periplasmic cytochromes and blue copper proteins could replace each other during growth of an obligate methylotroph (organism 4025) on methanol and methylamine. This was done by varying the relative concentrations of these proteins as a result of varying the amount of copper added to the growth medium during growth in oxygen-limited conditions. It was shown that the amount of added copper required for maximum growth was greater during growth on methylamine than on methanol. The concentrations of membrane-bound cytochromes $b, c$ and $o$ were not markedly affected by the copper concentration added to the growth medium whereas the concentrations of soluble cytochromes and blue copper proteins varied considerably. The concentrations of cytochrome $c_{\mathrm{L}}$ were highest at the copper concentrations giving maximum growth; this was more obvious during growth on methanol (when this cytochrome has a specific function) than on methylamine. The concentrations of blue copper proteins were highest at the copper concentrations which supported maximum growth (except for the absence of amicyanin during growth on methanol). In the absence of added copper, amicyanin could not be detected, and in the absence of added iron neither amicyanin nor 'azurin' was detectable. The most important conclusions are that high concentrations of amicyanin may not be essential for methylamine oxidation, that 'azurin' may replace cytochrome $c$ for some electron-transport functions, and that iron is required for synthesis of blue copper proteins.
\end{abstract}

\section{INTRODUCTION}

Methylamine dehydrogenase is a quinoprotein in which the prosthetic group (pyrroloquinoline quinone, $\mathrm{PQQ}$ ) is covalently bound (de Beer et al., 1980). It catalyses the oxidation of methylamine in many methylotrophs able to grow on this substrate, or on substituted methylated amines, as sole source of carbon and energy (Eady \& Large, 1968, 1971; Anthony, 1982, 1988). Growth on methylamine leads to induction of synthesis of methylamine dehydrogenase together with a novel type I blue copper protein called amicyanin (Tobari \& Harada, 1981; Tobari, 1984; Anthony, 1988). This is usually the only electron acceptor for the dehydrogenase, although in the obligate methylotroph, bacterium W3A1 it has not been observed, and it has been suggested that a cytochrome $c$ might replace it (Chandrasekar \& Klapper, 1986). This has also been suggested for Methylobacterium extorquens AM1 (Pseudomonas AM1) during growth in batch culture with low copper concentrations (see Tobari \& Harada, 1981; Tobari, 1984; Fukumori \& Yamanaka, 1987).

The subject of the present investigation, organism 4025, is a non-pigmented, Gram-negative, obligate methylotroph unable to grow on methane but able to grow on methanol or methylamine (Johanides et al., 1979; Vrdoljak \& Froud, 1982). Although similar in many respects to other obligate methylotrophs (Anthony, 1982), this organism is unusual in its response to copper in the growth medium, maximum growth only occurring on methanol or methylamine at high copper

Abbreviation: TMPD, $N, N, N^{\prime}, N^{\prime}$-tetramethyl-p-phenylenediamine. 
concentrations (Vrdoljak et al., 1984), when it is able to produce very large amounts of blue copper proteins (amicyanin and an azurin-type protein which is referred to as 'azurin') (Lawton \& Anthony, 1985a,b). It thus appears to be a particularly suitable organism for the study of the role of blue copper proteins in methylotrophs. Organism 4025 is similar to other methylotrophs in containing at least two periplasmic $c$-type cytochromes (Lawton \& Anthony, 1985 $a, b$; Anthony, 1986, 1988). These are cytochrome $c_{\mathrm{H}}$, a typical, small basic cytochrome, and cytochrome $c_{\mathrm{L}}$, which is the large acidic cytochrome that is the specific electron acceptor for the quinoprotein methanol dehydrogenase (Beardmore-Gray et al., 1983; Anthony, 1986, 1988). Organism 4025 contains no $a$-type cytochrome and it has been concluded that the only oxidase present is the $o$-type oxidase, cytochrome co (Lawton \& Anthony, 1985b; Auton \& Anthony, 1989).

The aim of the present study was to investigate the role in this unusual organism of copper on the synthesis of blue copper proteins and cytochromes in order to determine the extent to which these proteins might be able to replace each other in energy-transducing pathways during oxidation of methanol and methylamine. It has led to the important proposals that during growth with high concentrations of copper 'azurin' might replace cytochrome $c$ in electrontransport chains of this organism, and that iron is essential for synthesis of blue copper proteins.

\section{METHODS}

Growth of bacteria, and preparation of bacterial extracts and membranes. Maintenance of cultures, growth of organism 4025 in batch culture, cell harvesting, breakage and preparation of extracts and membrane fractions were as described previously (Lawton \& Anthony, 1985a,b).

Growth in oxygen-limited continuous culture. Bacteria were grown in a chemostat of 1 litre culture volume at a dilution rate of $0.15 \mathrm{~h}^{-1}$. The culture medium contained $\left(\mathrm{g} \mathrm{l}^{-1}\right): \mathrm{KH}_{2} \mathrm{PO}_{4}, 0.4 ;\left(\mathrm{NH}_{4}\right)_{2} \mathrm{HPO}_{4}, 4.0 ; \mathrm{KCl}, 0.2$ and $\mathrm{MgSO}_{4} .7 \mathrm{H}_{2} \mathrm{O}, 0.4 ;$ plus $10 \mathrm{ml}$ trace element solution based on that of Vrdoljak et al. (1984). The trace element solution contained $\left(\mathrm{mg} \mathrm{l}^{-1}\right): \mathrm{H}_{3} \mathrm{BO}_{3}, 30 ; \mathrm{MnSO}_{4} .4 \mathrm{H}_{2} \mathrm{O}, 20 ; \mathrm{ZnSO}_{4} .7 \mathrm{H}_{2} \mathrm{O}, 20 ; \mathrm{NaMoO}_{4} \cdot 2 \mathrm{H}_{2} \mathrm{O}, 40$; $\mathrm{CaCl}_{2} .2 \mathrm{H}_{2} \mathrm{O}, 530$; and $\mathrm{CoCl}_{2} .6 \mathrm{H}_{2} \mathrm{O}, 40$. Iron sulphate $\left(2 \mathrm{mg} \mathrm{l}^{-1}\right.$ of $\left.\mathrm{FeSO}_{4} \cdot 7 \mathrm{H}_{2} \mathrm{O}\right)$ and copper sulphate $(0-5 \mathrm{mg}$ $1^{-1}$ of $\mathrm{CuSO}_{4} .5 \mathrm{H}_{2} \mathrm{O}$ ) were added to the medium separately. No chelating agent was added and no precipitate was observed before growth. Methanol $(2.25 \%, \mathrm{v} / \mathrm{v})$ or methylamine hydrochloride $(1.5 \%, \mathrm{w} / \mathrm{v})$ was added and the complete medium filter-sterilized directly into a 20 -litre reservoir attached to the chemostat.

Copper-deficient media were prepared by using Analar-grade reagents made up with distilled and de-ionized water in glassware washed in chromic acid. Any copper in these media was below the limits of detection by atomic absorption spectroscopy, using a Perkin-Elmer 560 spectrometer, measuring absorbance at $324.7 \mathrm{~nm}$. The concentration of copper in growth media to which no copper had been added was equivalent to less than $0.1 \mathrm{mg}$ $\mathrm{CuSO}_{4} .5 \mathrm{H}_{2} \mathrm{O}^{-1}$; this was the lowest concentration of copper that could accurately be determined in growth medium by atomic absorption spectroscopy. During growth the $\mathrm{pH}$ of the culture was maintained at 6.8 by automatic addition of a sterile $\mathrm{NaOH} / \mathrm{KOH}$ solution, and Berox B-125 antifoaming agent was added by a timed mechanism. The air flow rate was 1 litre $\mathrm{min}^{-1}$ and the stirrer rate was 500 r.p.m. Diminishing the flow rate or the stirrer speed decreased the cell density, and the dissolved oxygen concentration was always below the limit of detection of a lead/silver oxygen electrode (L. H. Engineering Co.). Cell density was measured spectrophotometrically at $650 \mathrm{~nm}$, dry weight being estimated using a standard curve.

Measurement of bacterial respiration. This was done using a Rank oxygen electrode with a final reaction volume of $2 \mathrm{ml}$, and a substrate concentration of $10 \mathrm{mM}$ at $30^{\circ} \mathrm{C}$; it was assumed that the concentration of oxygen was $445 \mu \mathrm{M}$.

Determination of cytochrome oxidase. Oxidase activity was measured in an oxygen electrode $(2 \mathrm{ml})$ with horse heart cytochrome $c(100 \mu \mathrm{M}$; Sigma type III) in the presence of excess $(2 \mathrm{mM})$ ascorbate in $25 \mathrm{mM}$-MOPS buffer $(\mathrm{pH} 7 \cdot 0)$.

Determination of cytochromes and blue copper proteins. The concentrations of these proteins in the soluble fractions of bacteria were determined after their separation by chromatography. Absorption coefficients were taken from Lawton \& Anthony (1985a). Soluble extracts were first chromatographed on Pharmacia DEAESepharose (fast flow) in a $2.6 \times 5 \mathrm{~cm}$ column equilibrated in $50 \mathrm{mM}-\mathrm{MOPS}$ buffer $\left(\mathrm{pH} 7.0\right.$ ). Cytochrome $c_{\mathrm{L}}$ was the only component to adsorb to the column; after washing in the equilibration buffer containing $250 \mathrm{~mm}-\mathrm{NaCl}$, it was eluted with $350 \mathrm{mM}-\mathrm{NaCl}$. Cytochrome $c_{\mathrm{H}}$ did not adsorb to the column and could be measured directly. 'Azurin' and amicyanin were then separated from other proteins on a Bio-Rad hydroxylapatite (Biogel HTP) column $(1 \times 5 \mathrm{~cm})$ equilibrated with $50 \mathrm{mM}$-potassium phosphate $(\mathrm{pH} 7.0)$. They were eluted together by $200 \mathrm{mM}$ phosphate and then separated from each other by hydrophobic interaction chromatography using Pharmacia Phenyl-Superose HR $5 / 5$ equilibrated in $22.5 \%(\mathrm{w} / \mathrm{v})$ ammonium sulphate at room temperature. The 
concentrations of membrane-bound cytochromes were measured using reduced-minus-oxidized difference spectra taken at $77 \mathrm{~K}$ as described previously (Cross \& Anthony, 1980); the absorption coefficients were $22 \mathrm{mM}^{-1} \mathrm{~cm}^{-1}$ $(558 \mathrm{~nm}-575 \mathrm{~nm})$ for cytochrome $b$, and $19 \mathrm{~mm}^{-1} \mathrm{~cm}^{-1}(550 \mathrm{~nm}-535 \mathrm{~nm})$ for cytochrome $c$.

Determination of phospholipid and protein. The phospholipid content of bacteria and membranes was determined by the method of Bartlett et al. (1959) as modified by Kates (1972). Protein was determined by the bicinchoninic acid method as described by Smith et al. (1988).

\section{RESULTS}

\section{Effect of copper on growth and respiration in batch cultures}

In order to study the effect of copper concentration on the characteristics of organism 4025 it was necessary to use continuous culture. However, the first results obtained with this technique were sufficiently surprising compared with some previous results obtained using batch culture (Lawton \& Anthony, 1985b) that it was thought advisable to repeat these previous experiments. It was therefore confirmed that adding copper to the growth medium increased the rate and extent of growth on methanol and methylamine as described previously by Vrdoljak et al. (1984). The effect of growth substrate on the composition of the respiratory chain of organism 4025 during growth with sufficient copper $\left(0.5 \mathrm{mg} \mathrm{CuSO} 4.5 \mathrm{H}_{2} \mathrm{O}^{-1}\right)$ was also investigated, and the conclusions of Lawton \& Anthony $(1985 b)$ were confirmed: the concentrations of membrane cytochromes $b$ and $c$, and of soluble cytochrome $c_{\mathrm{L}}$, were very similar during growth on methanol and methylamine; by contrast, cytochrome $c_{\mathrm{H}}$ was induced 7-fold and 'azurin' 2-5-fold on methanol; and amicyanin was produced only during growth on methylamine.

Table 1 shows that the respiration rate with both methanol and methylamine as respiratory substrate was considerably higher after growth on methanol or methylamine with added copper. As shown previously with other bacteria (Anthony, 1982), methanol was oxidized after growth with both substrates whereas methylamine was oxidized only by bacteria grown on this substrate. With both substrates the respiration rate was considerably higher in bacteria grown in the presence of added copper. This is consistent with the expectation that the observed requirement for copper for high growth rates in these bacteria is in some way related to respiration, and this was confirmed in experiments using oxygen-limited cultures described below. Cultures in which the growth-limiting nutrient is the carbon substrate were not used in this work.

\section{Effect of copper on bacterial growth (culture density), respiration and composition of the respiratory membranes during oxygen-limited growth}

In all experiments described in this section the effect of increasing the concentrations of added copper during growth was reversible. That is, during a single chemostat run the level of added copper was first raised, then lowered, to show that the physiological changes could be

\section{Table 1. Effect of copper and growth substrate on respiration in bacteria grown in batch culture}

The endogenous respiration rate was approximately $5-10 \mathrm{nmol} \mathrm{m^{-1 }}(\mathrm{mg} \text { bacterial dry weight })^{-1}$. The concentration of copper (expressed as $\mathrm{CuSO}_{4} .5 \mathrm{H}_{2} \mathrm{O}$ ) in media without copper added was less than $0 \cdot 1 \mathrm{mg} \mathrm{l}^{-1}$ (determined by atomic absorption spectroscopy). The values given here are means of three determinations for each batch of cells; all values were within $\pm 5 \%$ of each other. Similar results to these were obtained when the experiment was repeated, the mean values being within $20 \%$ of those recorded here.

\begin{tabular}{|c|c|c|c|}
\hline & & $\begin{array}{r}\text { Respir } \\
{\left[\mathrm{nmol} \mathrm{O} \mathrm{min}^{-}\right.}\end{array}$ & $\begin{array}{l}\text { ion rate } \\
(\mathrm{mg} \text { dry } w t)^{-1} \text { ] }\end{array}$ \\
\hline $\begin{array}{l}\text { Growth } \\
\text { substrate }\end{array}$ & $\begin{array}{l}\text { added to medium } \\
\qquad\left(\mathrm{mg} \mathrm{l}^{-1}\right)\end{array}$ & $\begin{array}{l}\text { Methanol- } \\
\text { dependent }\end{array}$ & $\begin{array}{l}\text { Methylamine- } \\
\text { dependent }\end{array}$ \\
\hline $\begin{array}{l}\text { Methanol } \\
\text { Methanol }\end{array}$ & $\begin{array}{l}0 \\
2\end{array}$ & $\begin{array}{r}476 \\
1876\end{array}$ & $\begin{array}{l}0 \\
0\end{array}$ \\
\hline $\begin{array}{l}\text { Methylamine } \\
\text { Methylamine }\end{array}$ & $\begin{array}{l}0 \\
2\end{array}$ & $\begin{array}{r}23 \\
295\end{array}$ & $\begin{array}{r}20 \\
312\end{array}$ \\
\hline
\end{tabular}




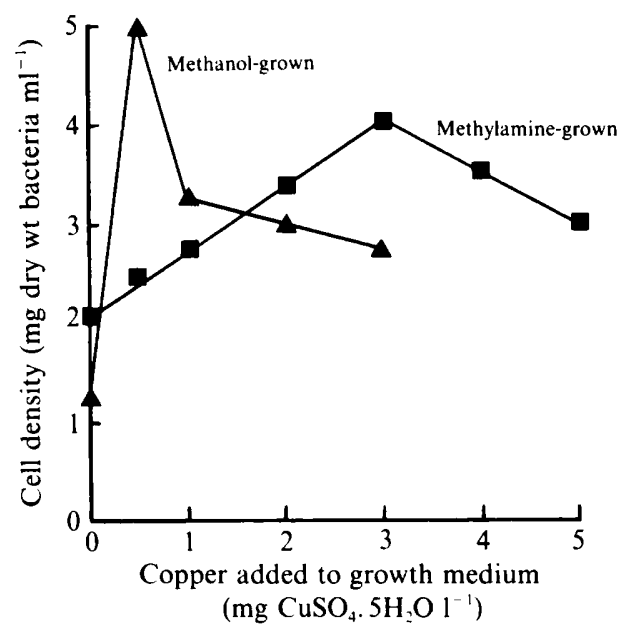

Fig. 1

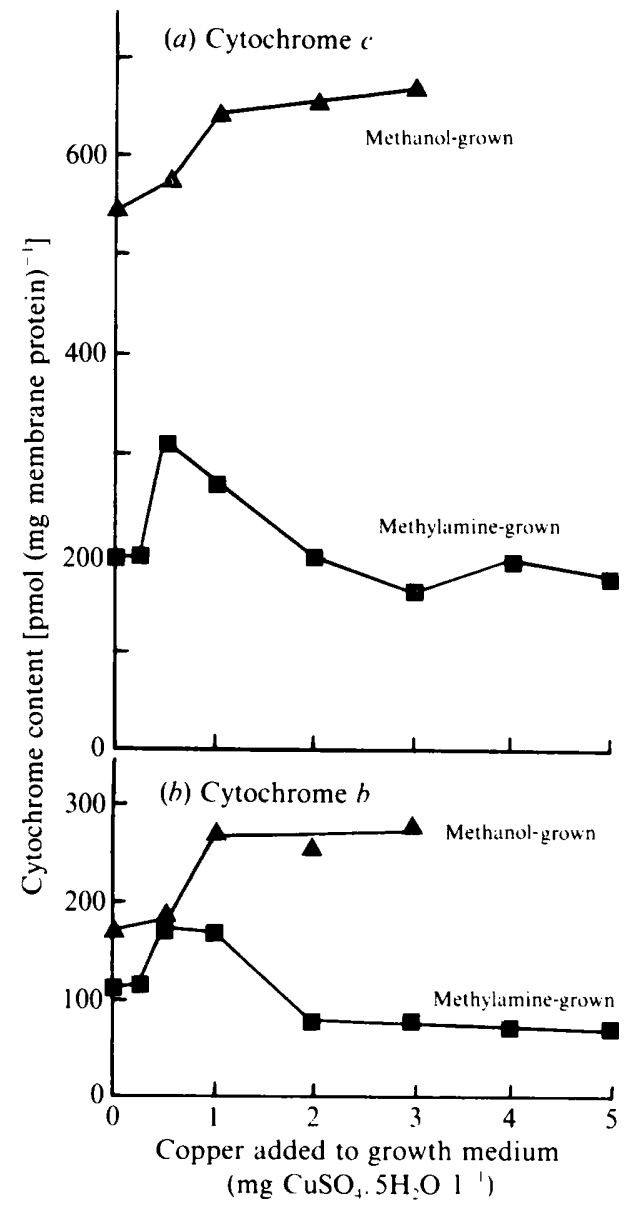

Fig. 2

Fig. 1. Effect of copper on bacterial density during growth in oxygen-limited continuous culture. Bacteria were grown at a dilution rate of $0.15 \mathrm{~h}^{-1}$. $\mathbf{}$, Growth on $1.5 \%(\mathrm{w} / \mathrm{v})$ methylamine; $\boldsymbol{\Delta}$, growth on $2.5 \%(\mathrm{w} / \mathrm{v})$ methanol. Determinations of dry weight were done on three separate samples for each growth condition and the mean taken (values were within $5 \%$ of each other). The experiment presented here was the same as that from which all data were obtained in Figs 2-4. When this particular experiment (effect of copper on growth) was repeated (separate series of cultures), almost identical values were recorded as given in this Figure.

Fig. 2. Effect of copper on synthesis of membrane-bound cytochromes $c$ (part $a$ ) and $b$ (part $b$ ). Bacteria were grown as described in Fig. 1: , methylamine-grown bacteria; $\Delta$, methanol-grown bacteria. The values recorded here are from the same series as presented in Figs 1, 3 and 4. When repeated (separate series of cultures) similar results were obtained (trends were identical, and individual values were within about $10 \%$ of those recorded here).

directly attributed to the copper concentrations. The concentrations of electron-transport proteins were the same (within the limits given on each Figure) whether the growth condition had been approached from a lower or a higher concentration of added copper.

The results for Fig. 1 show that the optimum concentration of $\mathrm{CuSO}_{4} .5 \mathrm{H}_{2} \mathrm{O}$ for growth on methanol was less than $0.5 \mathrm{mg} \mathrm{l}^{-1}$, whereas that for growth on methylamine was at least six times higher $\left(3 \mathrm{mg} \mathrm{l}^{-1}\right)$.

It should be noted that all cultures used were oxygen-limited and that the effect of copper concentration is an additional effect. The use of the expression 'dual limitation' has been 
avoided because it might imply an interpretation of the mechanism of the copper effect; insufficient information is available from the present work to make any definite statements about this.

Measurements of the respiration rates of bacteria removed from the cultures growing on methylamine showed that the increase in growth with increasing copper concentration correlated with an increasing respiration rate with methylamine. This rate was about $120 \mathrm{nmol}$ $\min ^{-1}(\mathrm{mg} \text { dry weight })^{-1}$ in the absence of added copper and about twice this rate with copper added sufficient for maximum growth $\left(3 \mathrm{mg} \mathrm{CuSO}_{4} .5 \mathrm{H}_{2} \mathrm{O}^{-1}\right)$.

As previously shown in batch cultures, membranes of organism 4025 grown under conditions of oxygen limitation contained only $b$ - and $c$-type cytochromes. In all growth conditions 25 to $40 \%$ of the cytochrome $b$ reacted rapidly with $\mathrm{CO}$, indicating the presence of an $o$-type oxidase. These bacteria contain neither cytochrome $a$ nor cytochrome $d$ and it is probable that the only oxidase present is an $o$-type oxidase of the cytochrome co category which has been partially purified from this organism (Auton \& Anthony, 1989). It is probable that the CO-reactive cytochrome $b$ measured in the present work is the cytochrome $o$ component of this cytochrome co oxidase.

The results summarized in Fig. 2 show that the total concentration of cytochromes in membranes of methanol-grown bacteria was higher than that in bacteria grown on methylamine. Neither the amounts nor the ratios of the two types of membrane-bound cytochrome varied markedly with growth substrate or copper concentration. The specific activity of oxidase in the membranes (only measured during growth on methylamine) likewise did not vary greatly with copper concentration $\left[0.3\right.$ to $0.6 \mathrm{nmol} \mathrm{O} \mathrm{min}^{-1}$ (mg membrane protein $)^{-1}$ using cytochrome $c$ as substrate]. It should be noted that the alternative polarographic assay using TMPD as substrate could not be used for this work because the membranes from bacteria grown at high copper concentrations contained copper which appeared to stimulate an oxidase-independent oxidation of TMPD.

An unexpected observation during this work was that although the concentrations of cytochromes (per mg membrane protein) did not vary markedly with changing copper concentrations, the membranes were much less pink when bacteria were grown at higher copper concentrations This correlated with the ratio of phospholipid to protein in the membranes. During oxygen-limited growth, with methylamine or methanol, the presence of added copper ( $3 \mathrm{mg} \mathrm{CuSO} \mathrm{m}_{4} \cdot 5 \mathrm{H}_{2} \mathrm{O}^{-1}$ ) decreased the ratio of phospholipid to protein in membranes to 30 to $40 \%$ of the value in the absence of added copper. A similar, but less marked effect was seen in bacteria grown in batch culture.

\section{Effect of copper on the concentrations of soluble c-type cytochromes and blue copper proteins during oxygen-limited growth on methanol and methylamine}

In all experiments described in this section the effect of increasing the concentrations of added copper during growth was shown to be reversible, as described in the preceding section. The concentrations of electron-transport proteins were the same (within the limits given on each Figure) whether the growth condition had been approached from a lower or a higher concentration of added copper.

The results in Fig. 3(a) show that the concentration of cytochrome $c_{\mathrm{L}}$, the electron acceptor for methanol dehydrogenase, was usually higher during growth on methanol than on methylamine; the highest concentrations were recorded at the copper concentration giving maximum bacterial density for each substrate (see Fig. 1). The concentration of cytochrome $c_{\mathrm{H}}$ was usually similar to or lower than that of cytochrome $c_{\mathrm{L}}$. Its concentration during growth on methanol was only slightly affected by the copper concentration; on methylamine, by contrast, there was a wider range of concentrations, the peak concentration correlating with the maximum growth density (Fig. $3 b$ ).

The results in Fig. 4(a) confirmed previous observations, using batch culture, that amicyanin is only produced during growth on methylamine and not on methanol. High concentrations of added copper were required for maximum synthesis, which occurred at the same copper concentration as required for maximum growth (cell density) (Fig. 1). A most remarkable 


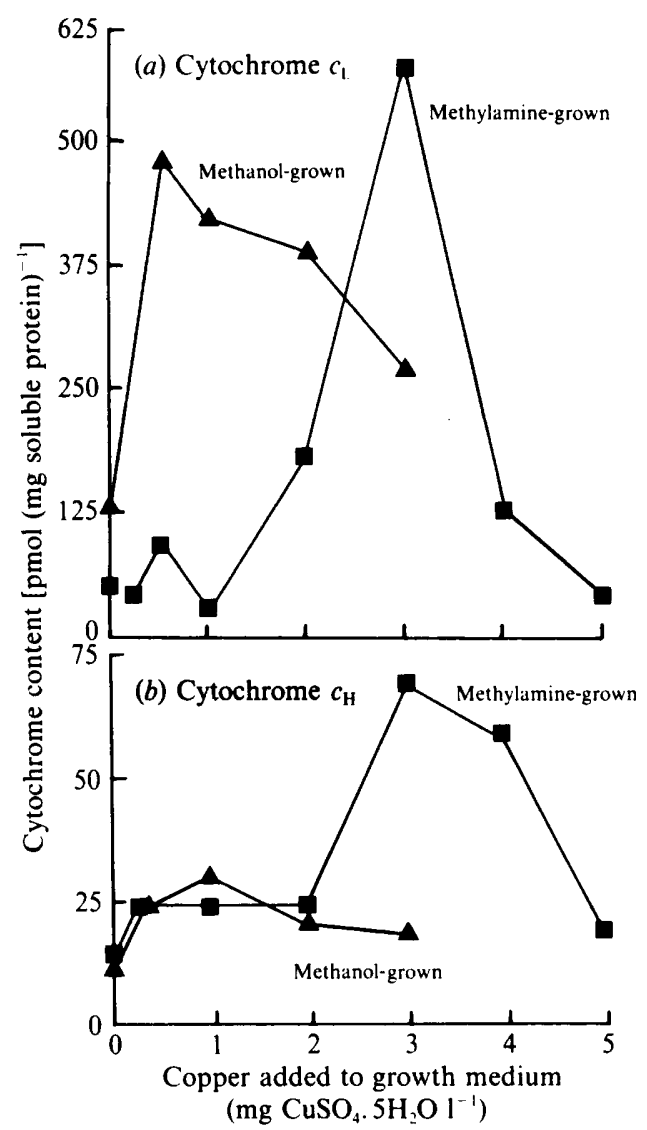

Fig. 3

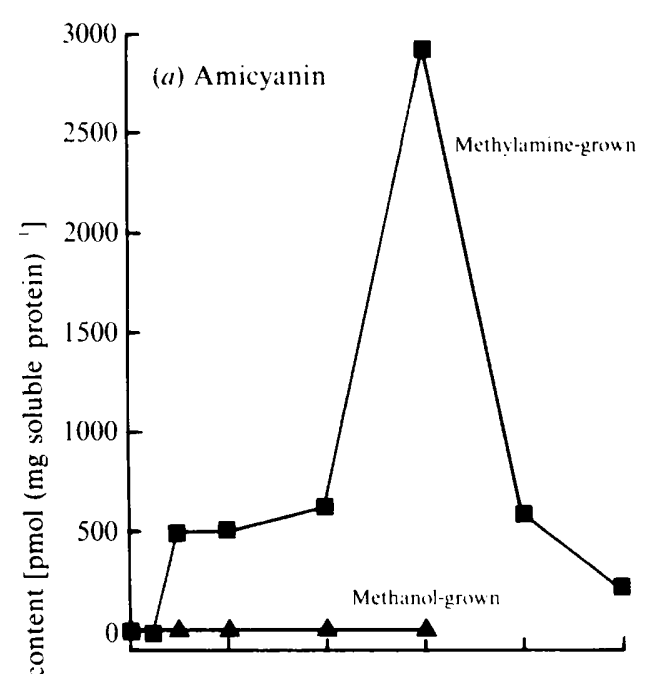

Fig. 3. Effect of copper on synthesis of soluble cytochromes $c$ (part $a$, cytochrome $c_{\mathrm{L}}$; part $b$, cytochrome $c_{\mathrm{H}}$ ). Bacteria were grown as described in Fig. 1: $\boldsymbol{\omega}$, methylamine-grown bacteria; $\boldsymbol{\Delta}$, methanol-grown bacteria. The concentrations of the $c$-type cytochromes were determined after their separation by anion-exchange chromatography (see Methods). The values recorded here are from the same series as presented in Figs 1, 3 and 4. When repeated (separate series of cultures) similar results were obtained (trends were identical, and individual values were within about $15 \%$ of those recorded here).

Fig. 4. Effect of copper on synthesis of blue copper proteins ( $a$, amicyanin; $b$, 'azurin'). Bacteria were grown as described in Fig. 1: $\boldsymbol{\square}$, methylamine-grown bacteria; $\boldsymbol{\Delta}$, methanol-grown bacteria. Amicyanin and 'azurin' were measured after separation by chromatography (see Methods). The values recorded here are from the same series as presented in Figs 1-3. When repeated (separate series of cultures) similar results were obtained (trends were identical, and individual values were within about $15 \%$ of those recorded here).

observation was that in the absence of added copper (less than $0 \cdot 1 \mathrm{mg} \mathrm{CuSO} \mathrm{Cu}_{4} \cdot 5 \mathrm{H}_{2} \mathrm{O}^{-1}$ ) growth on methylamine ocurred in the absence of measurable amicyanin [the limit of detection was about 10 pmol amicyanin (mg soluble protein $)^{-1}$.

The second blue copper protein is usually called azurin, although there is no evidence that it plays any role in nitrite reduction and its sequence is not known for comparison with other true azurins. During growth on methanol this protein was only produced at higher copper concentrations (Fig. $4 b$ ); none was produced at the concentration of copper at which maximum growth occurred, although at higher concentrations $\left(3 \mathrm{mg} \mathrm{1}^{-1}\right)$ there was four times as much 'azurin' as cytochrome $c_{\mathrm{H}}$. During growth on methylamine the peak concentration of 'azurin' was produced at the copper concentration at which maximum growth occurred (Fig. $4 b$ ). 


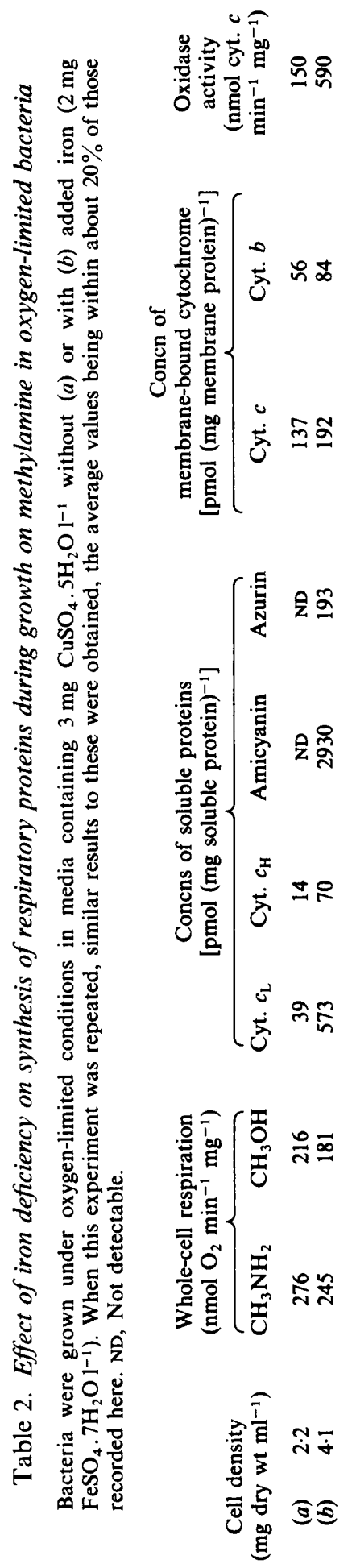




\section{Effect of iron deficiency on synthesis of respiratory proteins during growth on methylamine under oxygen limitation}

In preliminary experiments to investigate the possibility that blue copper proteins might be able completely to replace the soluble cytochromes during growth on methylamine, the effect of iron deficiency on bacteria growing on methylamine under oxygen limitation was determined. The results in Table 2 show that when no iron was added to growth medium containing sufficient copper for maximum growth, the cell density was halved and the concentrations of soluble cytochromes were markedly diminished. The membrane cytochromes and overall respiration rates were not markedly affected by the absence of added iron, although the oxidase activity of membranes was lower in its absence. The most remarkable result was that, although the copper concentration was high, no synthesis of either of the blue copper proteins occurred when no iron was added to the growth medium. The changes described in Table 2 were reversible; that is, when iron was added to the chemostat culture the concentrations of blue copper proteins and cytochromes, and oxidase activity, returned to the usual values measured in the presence of iron plus added copper $\left(3 \mathrm{mg} \mathrm{CuSO} 4 \cdot \mathrm{H}_{2} \mathrm{Ol}^{-1}\right)$.

\section{DISCUSSION}

\section{Growth on methanol}

The results described above show that when methanol is sole source of carbon and energy, less copper is required for maximum growth than with methylamine as substrate. Maximum cell density occurred at copper concentrations giving the highest concentration of cytochrome $c_{\mathrm{L}}$, the specific electron acceptor for methanol dehydrogenase. At this concentration of copper no 'azurin' or amicyanin was produced, consistent with the previous conclusion that the only soluble electron-transport proteins necessary for growth on methanol are the periplasmic methanol dehydrogenase and $c$-type cytochromes (Anthony, 1982, 1986, 1988). By contrast, at the higher copper concentrations that gave lower growth with methanol but maximum growth with methylamine, 'azurin' was induced to five times the concentration of cytochrome $c_{\mathrm{H}}$, suggesting that in these unusual conditions the oxidation of methanol might involve this blue copper protein as well as the two $c$-type cytochromes, as has been recently demonstrated using pure proteins (see below).

\section{Growth with methylamine}

With methylamine as substrate, amicyanin was induced to very high levels, the highest correlating with the copper concentration giving maximum growth, when all of the cytochromes and 'azurin' were also produced at their highest concentrations. In these conditions the 'azurin' concentration was three times higher than that of cytochrome $c_{\mathrm{H}}$, suggesting that it is able to replace this cytochrome (as suggested for methanol, above) in mediating electron transport to the oxidase. That this is an important possibility has recently been demonstrated by reconstituting a complete 'methylamine oxidase' system consisting of pure methylamine dehydrogenase, amicyanin and 'azurin' with partially purified cytochrome co oxidase (Auton \& Anthony, 1989).

The most unexpected observation during growth with methylamine was that at the lower concentrations of copper (less than $0 \cdot 1 \mathrm{mg} \mathrm{l}^{-1}$ ) no amicyanin or 'azurin' could be detected and yet half the maximum cell density was achieved. Similar results were obtained when no iron was added to growth medium containing the optimum amount of copper for growth on methylamine; no blue copper proteins were detectable in these bacteria and yet the respiration rate was not markedly altered. Clearly, this suggests that an alternative electron acceptor such as a cytochrome must be able to replace amicyanin for methylamine dehydrogenase, although work with purified proteins has shown that neither cytochrome $c_{\mathrm{H}}$ nor cytochrome $c_{\mathrm{L}}$ is able to fulfil this function in organism 4025 (Lawton \& Anthony, 1985a; Auton \& Anthony, 1989). 


\section{Conclusion}

It is evident that organism 4025 is able to produce far higher concentrations of soluble electron-transport proteins than are required for good (though not maximum) growth. There is no obvious reason for this, and the high requirement for added copper has not been explained.

It is clear that, although extraordinarily high concentrations of amicyanin are produced when sufficient copper is added to yield maximum growth, these high levels are not essential for growth on methylamine. Either extremely low levels of amicyanin are able to mediate electron transport from methylamine dehydrogenase, or amicyanin is able to be replaced by some unknown alternative electron acceptor.

During growth with sufficient added copper to yield maximum growth on methylamine, a novel electron-transport chain possibly operates in which the only soluble components are the blue copper proteins, as has been proposed previously from work with pure proteins (Auton \& Anthony, 1989). At these high copper concentrations cytochrome $c_{\mathrm{H}}$ may also be replaced by 'azurin' during growth on methanol.

Finally, this work has demonstrated for the first time, as far as we are aware, that iron may be involved in the synthesis of blue copper proteins.

We should like to thank the SERC and Pharmacia for financial support.

\section{REFERENCES}

ANTHONY, C. (1982). The Biochemistry of Methylotrophs. London: Academic Press.

ANTHONY, C. (1986). The bacterial oxidation of methane and methanol. Advances in Microbial Physiology 27, 113-210.

ANTHONY, C. (1988). Quinoproteins and energy transduction. In Bacterial Energy Transduction, pp. 293316. Edited by C. Anthony. London: Academic Press.

Auton, K. A. \& Anthony, C. (1989). The 'methylamine oxidase' system of an obligate methylotroph. Biochemical Journal 260, 75-79.

Bartlett, G. R. (1959). Phosphorous assay in column chromatography. Journal of Biological Chemistry 234, 466-468.

Beardmore-Gray, M., O'KeEfFe, D. T. \& ANThony, C. (1983). The methanol:cytochrome $c$ oxidoreductase activity of methylotrophs. Journal of General Microbiology 129, 923-933.

de Beer, R., Duine, J. A., Frank, J. \& Large, P. J. (1980). The prosthetic group of methylamine dehydrogenase from Pseudomonas AM1. Biochimica et biophysica acta 622, 370-374.

ChandraseKar, R. \& Klapper, M. H. (1986). Methylamine dehydrogenase and cytochrome $c_{552}$ from the bacterium W3A1. Journal of Biological Chemistry 261, 3616-3619.

Cross, A. R. \& ANThONY, C. (1980). The electron transport chains of the obligate methylotroph Methylophilus methylotrophus. Biochemical Journal 192, 429-439.

EADY, R. R. \& LARge, P. J. (1968). Purification and properties of an amine dehydrogenase from Pseudomonas AMl and its role in growth on methylamine. Biochemical Journal 106, 245-255.

EADY, R. R. \& LARGE, P. J. (1971). Microbial oxidation of amines. Spectral and kinetic properties of the primary amine dehydrogenase of Pseudomonas AM1. Biochemical Journal 123, 757-771.

FUKUMORI, Y. \& YAMANAKA, T. (1987). The methylamine oxidising system of Pseudomonas AM1 recon- stituted from purified components. Journal of Biochemistry 101, 441-445.

Johanides, V., VRdoljaK, M. \& Maric, V. (1979). A selection of methylotrophic bacteria for single cell protein production from methanol. Acta biologica jugoslavica - mikrobiolojica 16, 1-9.

KATES, M. (1972). Techniques of lipidology. In Laboratory Techniques in Biochemistry and Molecular Biology, vol. 3. Edited by T. S. Work \& D. Work. Amsterdam: North Holland Publishing Company.

LAwTon, S. A. \& ANTHONY, C. (1985a). The role of blue copper proteins in the oxidation of methylamine by an obligate methylotroph. Biochemical Journal 228, 719-725.

LAwTON, S. A. \& ANThony, C. (1985b). The roles of cytochromes and blue copper proteins in the oxidation of methanol and methylamine in organism 4025 , an obligate methylotroph. Journal of General Microbiology 131, 2165-2171.

Smith, A., Hill, S. \& ANThoNy, C. (1988). A haemoprotein is not involved in the control by oxygen of enteric nitrogenase synthesis. Journal of General Microbiology 134, 1499-1507.

ToBARI, J. (1984). Blue copper proteins in electron transport in methylotrophic bacteria. In Microbial Growth on $C_{1}$-compounds, pp. 106-112. Edited by C. L. Crawford \& R. S. Hanson. Washington, DC: American Society for Microbiology.

TOBARI, J. \& HaRADA, Y. (1981). Amicyanin: an electron acceptor of methylamine dehydrogenase. Biochimica et biophysica acta 101, 502-508.

VRDOLJAK, M. \& FROUD, S. J. (1982). Characterisation of the electron transport chain of an obligate methylotroph strain 4025. International Journal of Biochemistry 14, 1019-1023.

VRdoljaK, M., Maric, V. \& Johanides, V. (1984). Copper requirement and its influence on the growth of the obligate methylotrophic bacterial strain 4025 . Biotechnology Letters 6, 501-506. 